\title{
Andean Indigenous Sustainable Development
}

Indigenous development has been institutionalized in the Andean region more than in any other region in the world (with the possible exception of Bhutan). This is most apparent when we consider the constitutions of Ecuador and Bolivia, in which multiple indigenous concepts of governance and citizenship have been enshrined (Schilling-Vacaflor 2010; Hidalgo-Capitán et al. 2019). Debates over the particularities of these national constitutions notwithstanding, these Andean countries provide an essential case study of indigenous sustainable development. Taken together, the 40 million-plus indigenous citizens of Bolivia and Ecuador represent 20 percent of the entire indigenous population of Latin America (Yashar 1999). This manifests an indigenous majority in Bolivia and large minority in Ecuador. Given the relative size of the indigenous populations in these countries, along with other historical, economic, and political particularities, it should not be surprising that indigeneity has had such force in the region. This chapter will examine the case of Ecuador specifically, as it provides a prescient example of the entanglements (Radcliffe et al. 2002) involved in the mainstreaming indigenous sustainable development.

\section{Indigeneity AND NATION-BUILDING In ECUADOR}

Struggles of indigenous groups within the country have often dovetailed with efforts of international agencies towards ethnodevelopment, helping to produce a uniquely indigenized politics in Ecuador. Classification is an 
issue with defining indigeneity in the country, but it has been estimated that the indigenous population is somewhere between $7 \%$ and $40 \%$ of the total population. This indigenous population is significantly poorer than the Mestizo majority (Radcliffe et al. 2002; Masala and Monni 2017). Since the mid-twentieth century, numerous indigenous groups of the country have organized politically. Initially, this organization was focused on local associations, then more regional affiliations, and, since the mid-1980s, national confederations were formed. As a result of this work, Ecuador has developed one of the strongest national indigenous rights movements in the world (Yashar 1996; Escobar and Alvarez 1992).

Not surprisingly, the most intense indigenous organizing began following externally imposed neoliberal restructuring in the 1980s. Extreme wage repression during the neoliberal period aggravated social conditions to the point that nearly $80 \%$ of the population lived in poverty by 1990 (Masala and Monni 2017). These issues were compounded by a fall in the price for oil-the country's main export-and a related crisis of inflation. These crises exacerbated the conditions of the country's poor, by pushing the unemployment rate to $30 \%$, and reducing real incomes drastically (SIISE 2015). The government dollarized the economy in 2000 in an attempt to address the inflation problem. This further increased poverty and inequality, stimulating a high volume of emigration to Canada and the United States (Acosta 2006). Ecuador's colonial history had assured that indigenous people were especially marginalized; therefore, despite a lack of ethnically disaggregated statistics before 2000 , we can expect that these crises impacted that group disproportionately. Social exclusion if indigenous peoples due to their geographical distance from power structures, poverty, and continued racism further diminished their status (Masala and Monni 2017).

As was the case throughout the globe, the neoliberal, and later postneoliberal, periods saw the rise of NGOs and other elements of civil society as the state was retracted. A global indigenous movement became especially forceful in 1992, with the 500-year anniversary of colonialism and the Nobel Prize of Rigoberta Menchu. Ecuadorian indigenous groups both took inspiration, and were integral to, this movement (Radcliffe et al. 2002). Largely in response to pressure from the transnationally linked national indigenous rights movement, Ecuador ratified ILO 169 in May 1998. This changed customary law significantly in the country and also related to a shift in cultural and political power for indigenous people-many of whom were appointed to important development boards or 
elected to congress (Radcliffe et al. 2002). This indigenous movement was integral to the broader-based Ecuadorian Revolución Ciudadana, which began to mobilize around values such as solidarity, equality, and dignity for indigenous peoples (Masala and Monni 2017).

Beginning around 2000, the postneoliberal period saw the injections of the concept of indigenous social capital into economic development theory. Due to perceived inadequacies in neoliberal marker fundamentalism, the idea that social capital could be harnessed as a corrective to market failures became widespread (Fine 2002). To those in the guiding global development institutions, indigenous culture became a marker for social capital. A World Bank working paper, for example, claims that

indigenous peoples in Ecuador suffer from economic deprivation but are well-endowed with social capital (for example, organization, solidarity patterns, and shared social and cultural values). (van Nieuwkoop and Uquillas 2000)

What has become known as ethnodevelopment encapsulates these ideas. Ancestral knowledge, reciprocity, non-market exchange, collective identity, a capacity to mobilize labour, and close attachment to ancestral lands have now all become key resources for ameliorating market failures according to development economists (Radcliffe et al. 2002). This, according to postneoliberal development economics, contributes to economic growth while lessening the probability of negative environmental consequences. As one World Bank report phrases it, "strengthening cultural identity and promoting sustainable socioeconomic development are mutually reinforcing" (Deruyttere 1997).

As a result of the mainstreaming of social capital and ethnodevelopment, funding and political support for indigenous groups intensified globally (Radcliffe et al. 2002). Ecuadorian indigenous institutions benefitted significantly from this. The World Bank, for example, created a $\$ 50$ million Indigenous and Afro-Ecuadorian Peoples' Development Project that was active from 1998 to 2003. The project specifically sought to facilitate land access and funding for indigenous communities and other groups. Its four goals included strengthening indigenous organizations, securing land and title for indigenous communities, providing investment in community infrastructure and micro-enterprise, and strengthening the National Council of Indigenous and Afro-Ecuadorian Development (World Bank 2019). Similarly, since 1996, multiple mainstream international agencies 
have funded the Fund for the Development of Indigenous Peoples in Latin America and the Caribbean (Fondo Indigena), from which Ecuadorian groups continually benefit (Fondo Indigena 2019). Fondo Indigena supports capacity building in indigenous civil society organizations as well as investing in community-level projects, cultural revitalization, and indigenous education.

Such programmes have increased the interpolating power of the national indigenous movement and of the Revolución Ciudadana. The result was an increased incorporation of the indigenous movement's four main goals into national politics in Ecuador. According to Radcliffe et al. (2002), these goals are "to strengthen their own cultures, to construct a plurinational state, to gain self-determination as a people with right to land and collective rights; and self-management of their own development" (p. 5).

Although indigenous movements in Ecuador have gained funding and legitimacy via postneoliberal development policy, it is important to note that the goals of movements such as Revolución Ciudadana align only partially with those of development economists and funding agencies. As Radcliffe et al. (2002) put it, "[u]nder social capital models culture is an asset, while for indigenous movements, culture represents a successful politics of anticolonialism" (p. 11). As social capital, indigenous culture is supposed to make markets work better, but new economic models of development have little theoretical space for the radical, communitarian, and often anti-capitalist politics of indigenous movements. Just as with examples from Guatemala and Honduras, this theoretical and practical misalignment provides opportunities for indigenous peoples at the same time as it introduces tensions. These tensions occur as the economic development imperatives of states and multilateral institutions misalign with alternatives to development often advocated by indigenous groups. These tensions become obvious when we consider the politics around the Andean indigenous concept of Sumak Kawsay and an associated plan for resource non-extraction in the Yasuni region.

\section{SumaK KaWsar and the Ecuadorian Constitution}

The Andean indigenous concept of Sumak Kawsay has received a good deal of attention recently as it is likely the most systematized, institutionalized, and clearly delineated proposal for an alternative to development that has emerged from Latin America. While the Maya of Guatemala and Garifuna in Honduras can only hope to attain the physical, discursive, and 
political resources required to systematize indigenous development, Ecuadorians have gone some distance in realizing a true alternative to modernization. This should not be taken to imply that Sumak Kawsay, and related policy and politics, has achieved a pure vision that has been systematically implemented. The concept and its use by indigenous communities and the state are embattled and multiply interpreted. Thus, studying the incongruencies associated with Sumak Kawsay allows us to understand better the pitfalls and possibilities involved in establishing and institutionalizing indigenous alternatives to development.

Although the concept of Sumak Kawsay is deeply rooted in indigenous cosmology, the concept has emerged only recently as welfare or development paradigm. Hidalgo-Capitán et al. (2019) explain that this formalization began with the Amazanga Plan, initiated by the Pastaza Indigenous Peoples' Organization of Ecuador in the early 1990s. The plan documented, for the first time, what is called the wisdom of the people of the jungle (sacha runa yachai in Kichwa). This "philosophical framework," according to Hidalgo-Capitán et al. $(2019$, p. 2), is embedded in three concepts. The first, Sumac Allpa, indicates a "land free of evil," the second, Sumak Kawsay, implies a "clear and harmonious life," and the third, Sacha Kawsay Riksina, evokes the "art of understanding-knowingconvincing-being" (ibid.). Carlos Viteri, a Kichwa anthropologist, then "systematized this concept until it became a theoretical proposal for welfare and a proposal for social transformation" (ibid.). Despite previous uses of the term, it is Viteri's ethnography-based synthesis that has been increasingly evoked by the signifier Sumak Kawsay.

The concept combines spiritual, ecological, and communitarian elements and rests on indigenous perceptions of multiple, interrelated spheres. The first of these, Amasanga, is described by Coq (2017) as "the spirit of the forest," which "acts as an energy that flows through an extended perception of the ecosystem" (p. 169). This extended notion of ecosystem includes animals and insects, humans, water, soil, as well as "spirits of the forest" (ibid.). Thus, Amasanga is "essential for understandings interconnections amongst different sets of elements (social, natural, spiritual)" (ibid.). Nunghui, according to Coq-Huelva et al. (2018), is the spirit of things that are made, or nurtured, by humanssuch as gardens or handicrafts. Vitally, this concept is also associated with equilibrium and stability. The third sphere of Sunghui, the source of life, is interrelated with the other two spheres. 
Sumak Kawsay is intimately related to these spheres as they interact within a given locality. Thus "people cannot be understood without territory, and territory cannot be understood without people" (ibid.). In turn, "[t]he community not only includes people but also animals, plants, ecosystems, even forces and spirits that supposedly live in the territory" (ibid.). Sumak Kawsay, therefore, implies the nurturance of well-being of this community that extends beyond the simple human elements, evoking the importance of balance with nature where human needs cannot predominate the well-being of nature. Consequently, according to Coq (2017), "[c] ommunitarian harmony is not only the product of but also the guarantee of good family living" (ibid.). Therefore, "having a good family and residing in a non-conflictive human community that conserves forests and their associated spirits are essential elements" of indigenous understandings of being (ibid.). This translates into a "preference for selfsufficiency," often articulated in terms of food sovereignty as well as a bio-centrism (ibid.).

Given these characteristics, Sumak Kawsay has found many allies in postneoliberal political and economic paradigms. The idea has resonated well with streams of decentralized new socialism that have emerged in twenty-first-century Latin America. Increasingly powerful discourses of sustainability and environmentalism have found a congruence with the concept as well. The global food sovereignty movement too supports, and is supported by, the idea (as well as the Andean indigenous movements that have propagated it). Furthermore, the idea that Andean indigenous peoples have a transcendent understanding and relation with nature fits well with the indigeneity-as-social-capital postulates of post-WashingtonConsensus development policy. All of these things have produced a perfect storm for the ascendance of Sumak Kawsay in Ecuador. As the idea has gained formality and popularity, however, its essence of localism and biocentrism may have been ejected. This can be seen clearly with the inclusion of the concept in the Constitution of Ecuador.

Due to the multiple political, economic, and discursive forces outlined above, Sumak Kawsay emerged at the forefront of the Ecuadorian political imagination in the period leading up to the institution of a new national constitution in 2008. Although the concept has a complex meaning that is differently interpreted in various locales (Uzendoski 2018; Coq 2017), it came to be translated to Bien Vivir (to live well) in Spanish. This was part of a massive undertaking by the leftist government of President Rafael Correa to create a national constitution that would be later touted as the 
"most radical in the world" (Lalander 2016, p. 623). Although that description may be appropriate, many tensions emerged with Sumak Kawsay's interpretation and institutionalization into the constitution. The most striking of these tensions is between the indigenous concept and attempts of the Correa government to simultaneously institute a new socialism. Following the emergent "red tide" in Latin America, this new socialism focused on decentralization and egalitarianism, funded by resource extraction.

The constitution of 2008 was propelled largely by the Revolución Ciudadana, which advocates "policy aimed at abolishing social stratification along ethnic, gender, religious and class lines" (Lalander 2016, p. 629). This abolishment of stratification does not mean the elimination of difference, however, as the Constitution's first article declares the country to be intercultural and plurinational. This recognition of difference in worldview along with a progressive, extractivist, model of development inspired many to label the Constitution as an exercise in "Sumak Kawsay Socialism," as opposed to being a definitive expression of indigenous ideals (Ramírez Gallegos 2012, p. 33). Thus, As Lalander (2016) argues, the use of Sumak Kawsay in the Ecuadoran Constitution signifies a process through which "ancient indigenous traditions are applied in new contexts to create alternatives to global capitalism" (p. 631) that are not necessarily in opposition to modernizing development. Consequently, recognition of indigenous relations to nature was secured amidst a national effort to intensify development through large-scale mining. Typifying the new commitment to indigenous cosmovision, Article 71 of the Constitution, states that:

Nature, or Pacha Mama, where life is reproduced and occurs, has the right to integral respect for its existence and for the maintenance and regeneration of its life cycles, structure, functions and evolutionary processes. [Furthermore] All persons, communities, peoples and nations can call upon public authorities to enforce the rights of nature. To enforce and interpret these rights, the principles set forth in the Constitution shall be observed, as appropriate. The State shall give incentives to natural persons and legal entities and to communities to protect nature and to promote respect for all the elements comprising an ecosystem.

Article 72 follows by declaring that nature has a right to be restored if it has incurred damages. Following this, Article 73 delineates measures that 
the government must take to prevent or restrict damage to the natural environment. Article 57 applies specific protection to peoples who are living in voluntary isolation, and to their environments. The article states that they "are an irreducible and intangible ancestral possession [of their land] and all forms of extractive activities shall be forbidden there." Subsequently, "[t]he State shall adopt measures to guarantee their lives, enforce respect for self-determination and the will to remain in isolation." In accordance, " $[\mathrm{t}]$ he violation of these rights shall constitute a crime of ethnocide." These articles are all in accordance with the sentiment extended in the preamble, which states:

We women and men, the sovereign people of Ecuador ... hereby decide to build a new form of public coexistence, in diversity and in harmony with nature, to achieve the good way of living, the Sumak Kawsay. (República del Ecuador 2008)

Lalander (2016) points out, however, that although the Constitution, and ILO 169, contain language emphasizing the right to free, prior, and informed consultation in the face of planned resource extraction in their territories, the related requirements are ambiguous. As Lalander (2016) suggests, the Constitution makes clear in multiple articles that the state has a responsibility to use natural resources in the interest of social welfare. For example, Article 276 delineates state development responsibilities:

1. To improve the quality of life and life expectancy, and enhance the capacities and potential of the population within the framework of the principles and rights provided for by the Constitution. 2. To build a fair, democratic, productive, mutually supportive and sustainable economic system based on the egalitarian distribution of the benefits of development and the means of production, and on the creation of decent, stable employment. (República del Ecuador 2008)

Although territorial and environmental protection remains uncommonly strong in the constitution, there are many such caveats. For example, Article 405 declares:

Activities for the extraction of nonrenewable natural resources are forbidden in protected areas and in areas declared intangible assets, including forestry production. Exceptionally, these resources can be tapped at the substantiated request of the President of the Republic and after a declaration of 
national interest issued by the National Assembly, which can, if it deems it advisable, convene a referendum. (República del Ecuador 2008)

The Constitution of Ecuador does, in general, stand as an exemplary and revolutionary document in its protections for plurinational indigenous rights and rights accorded to the natural environment. It is, however, an incorporation of some biocentric and indigenous principles into a developmentalist state apparatus that is interested in neo-extractivist newsocialist development. Development remains a form of modernization premised on resource-based economic growth, albeit one that emphasizes protections for nature and cultural alterity. The ambiguities generated by this document, and the cultural political economy in which it is situated, are visible in the politics around the failed Yasuní-ITT initiative.

\section{The $\Upsilon_{\text {Asuní Plan and Its Failure }}$}

Yasuní-ITT refers to the protected ecological area of the Yasuní National Park and three untapped oil blocks contained therein-known collectively as Ishpingo-Tambococha-Tiputini. Ecuador's main indigenous organization CONAIE demanded the suspension of exploitation of oil resources in the area in 1995 (Lalander 2016). The Tambococha and Tiputini both lived in voluntary isolation in Yasuní, and CONAIE claimed that their ancestral territories and ways of life were extremely vulnerable to expanded oil exploration (Fierro 2017). In 2007, before the national endorsement of the 2008 Constitution, President Correa and his government initiated a bold plan for the protection of the area, which contained some of the nation's largest oil reserves: the Yasuní-ITT initiative.

Purportedly following the spirit of Sumak Kawsay-which had become a guiding principal for both CONAIE and the federal government- the Yasuní-ITT proposed to keep all oil of the area "in the ground." The simple idea was to ask the international community to compensate Ecuador for half the loss of income it would incur due to the non-exploitation of oil. This would protect carbon sink, flora, and fauna in one of the most ecologically diverse areas of the world, and the way of life of the region's indigenous inhabitants, while providing social development funds (Lalandar 2016).

Specifically, as a UNDP document claims, the project would leave 846 million barrels of oil in the ground. This oil would be worth approximately 
$\$ 90$ billion in 2019-adjusted dollars. Since the government of Ecuador would voluntarily forfeit half the opportunity cost of the oil, Correa was seeking international support in gaining $\$ 45$ billion to establish a YasuníITT trust fund. Touted as a new model for development, this initiative specifically proposed the following:

(a) An innovative option for combatting global warming by avoiding the production of fossil fuels in areas that are highly biologically and culturally sensitive in developing countries.

(b) Protecting the biodiversity of Ecuador and protecting the voluntary isolation of indigenous cultures...

(c) Social development, nature conservation and implementing the use of renewable resources. (Larrea 2009, p. 2)

Capital gained via the fund would be invested in the production of renewable energy via solar, wind, and hydroelectric facilities. These would provide stable investment income thereafter. The profits of which, along with interest from the remainder in the fund, would be used for:

(a) $[\mathrm{C}]$ onserving and preventing deforestation ... in 43 protected areas, totaling 4.8 million hectares ... equaling $18 \%$ of Ecuador's territory

(b) Reforestation, forestation, natural regeneration and appropriate management of one million hectares of forest owned by small landholders

(c) Increase national energy efficiency

(d) Promote social development ... with programs that include health, education, training, technical assistance and productive job creation in sustainable activities. (Larrea 2009, p. 3)

The massive project would fund a national-scale attempt to diversify the economy away from a model of development based on oil extraction, towards a new strategy based on equity and sustainability. As Lalander (2016) claims, "the Yasuní-ITT initiative turned into the symbol of another possible world and a rejection of extractive capitalism" for progressives around the world (p. 633). The region and project became a "national refrain of Ecuadorians across the nation, around the identification of the environmentalist purposes of the initiative"; "I am Yasuní" ( $\Upsilon_{0}$ soy Yasuni) or "We are all Yasuní" (Todos somos Yasuni) became popular national slogans (ibid.). 
The project, however, reproduced tensions between the meaning of Sumak Kawsay for indigenous people, and its use by the national government and non-indigenous population. At its root, Sumak Kawsay is an alternative to development. The Yasuní-ITT initiative, however, espoused an alternative form of development. The difference is not trivial. One concept rejects modernization and elevates another, ecologically rooted, way of existing. The other concept advocates modernistic national development via a new-socialist and sustainable development model. Although indigenous groups such as CONAEI supported the initiative, this support was tentative, and such groups did not tend to support the Correa government in general (Lalander 2016).

Fierro (2017) explains that this tension also resulted from Ecuador's position as an oil-dependent developing country within a capitalist global political economy. The scale of the project was too large to be internally financed; thus, Correa had to turn to the international community of nations for funding. These donors balked at the framing of the project because it hinged on the non-extraction of resources. Germany, for example, announced that it would not offer finances because "the proposal is dangerous and might be a precedent for other producing countries to demand a similar amount" (AGENCIA AFP 2010). Although Germany supported many elements of the project, it could not "support the idea of paying compensation to a country for renouncing oil exploitation" (ibid.). Much of the international community balked in this same way, ultimately leaving the initiative virtually unfunded.

Ecuador was not in a position to leave the oil in the ground without compensation, however. The country was not only dependent on oil income, which equaled $66 \%$ of its total imports, it was also dependent on oil derivatives (refined petroleum, petrochemicals for agriculture, etc.). In all, $74 \%$ of the derivatives used in the country were imported (Acosta 2006). The abandonment of modernizationist development could not be supported by the non-indigenous majority (nor likely by many indigenous Ecuadorians). That the country could only premise non-extraction on payment from the international community, makes obvious its dependent position in the global economy. This dependency exists discursively-in the largely imported cultural norm of modernizationist development. It also exists economically - in the lack of funds available to pursue sustainable forms of modernization (Fierro 2017).

Correa cancelled the Yasuní-ITT initiative in August 2013. The Ecuadorian government had promoted the idea for six years, but sufficient 
funds were never accumulated. In an impassioned press conference, the president explained, "unfortunately we have to say that the world has failed us ... I think the initiative was ahead of its time, and those responsible for climate change were unable to understand it, or did not want to." In his mind, not only had the international community of nations let Ecuador down, but also the global environmental movement and associated individual progressives from all over the world also failed to put their finances behind the project.

But many have also pointed out that the failure was also on the Ecuadorian government's hands. They had promoted a green modernizationist development programme and de facto continued embedding of the country within an extractives capitalist world system instead of rejecting that system and pledging simply to keep the oil in the ground without financial strings attached. Sumak Kawsay was, in fact, never a cohesive part of the programme. It was a plan for modernization via green new-socialist principles. The plan purported to protect indigenous peoples, but did not take their ideas as seriously as it could have.

\section{Conclusion}

Sumak Kawsay, as the idea emanates from indigenous Ecuador, is unprecedented as a well-delineated alternative to development. It is biocentric as opposed to anthropocentric. This biocentrism is achieved as indigenous cosmovision extends the idea of community beyond the human domain and into the natural world. Nature is framed as something to be nurtured and maintained, instead of as a resource for development. There is an idea of development contained in Sumak Kawsay, however. This involves the complex ideal of the extended community "living well." This does not necessarily require economic growth or modernizationist development.

Sumak Kawsay emerged in a time typified by the forceful emergence of a neo-extractivist, new socialist model of development in Latin America (Villalba-Eguiluz \& Etxano 2017). This model aims to use resource extraction to create economic surplus that will be used to fund a decentralized, egalitarian, but modernizationist form of development. Environmental sustainability is not ejected in new-socialist development models, nor is the protection of indigenous peoples, their cultures, and their land. With their emphasis on economic diversification and equity along modernizationist lines, however, they clash with Sumak Kawsay, 
which is more closely aligned with a de-growth perspective that emphasizes well-being and nurturance of the extended community.

Furthermore, the ascendance of both new socialism and indigenous alternatives to development has emerged within a capitalist and extractivist global political economy. This global political economy favours indigeneity only so much as it is a corrective for market failures. Neoliberal multiculturalism assures that this acceptance of alterity stops where it clashes with capital accumulation. As a result, indigenous culture is supported in a superficial way. When Andean indigenous cosmovisions conjure proposals that eschew economic development via resource extraction, that support stops.

Thus, the Ecuadorian constitution simultaneously includes and excludes indigenous ideas of development. This case study, then, evidences not only a lack of resources that dependent nations have to pursue endogenous development priorities, but also shows a lack of empathy and imagination even amongst sympathetic developmentalist governments. As a result, indigenous alternatives to development have yet to be pursued seriously even in the most sympathetic and progressive governments of the world. Indigenous development in Ecuador does have obvious allies in global de-growth and deep-ecology movements, but these movements are not close to being mainstreamed. Sumak Kawsay, along with other forms of indigenous sustainable development, therefore, remains to be marginalized and incorporated only piecemeal. This is true whether they are incorporated by new socialist states such as Ecuador, or predatory, clientalist regimes such as those in Honduras or Guatemala.

\section{REFERENCES}

Acosta, A. (2006). Breve historia económica del Ecuador. Quito: Corporación Editora Nacional.

AGENCIA AFP. (2010, September 20). Ecuador Anuncia ante Alemania para conseguir apoyo al ITT, Diaro El Universo, Monday.

Coq-Huelva, D., Torres-Navarrete, B., \& Bueno-Suárez, C. (2018). Indigenous Worldviews and Western Conventions: Sumak Kawsay and Cocoa Production in Ecuadorian Amazonia. Agriculture and human values, 35(1), 163-179.

Correa, R. (2013, August 14). Press Conference. The Announcement of the Cancellation of the Yasuni-ITT Initiative, Given by President Correa.

Deruyttere, A. (1997). Indigenous Peoples and Sustainable Development: The Role of the Inter-American Development Bank. IND97-101, Inter-American Development Bank, Washington, DC. 
Escobar, A., \& Alvarez, S. (Eds.). (1992). The Making of Social Movements in Latin America: Identity, Strategy and Democracy. Boulder, CO: Westview.

Fierro, L. G. (2017). Re-thinking Oil: Compensation for Non-production in Yasuní National Park Challenging Sumak Kawsay and Degrowth. Sustainability Science, 12, 263-274.

Fine, B. (2002). Social Capital versus Social Theory. Routledge.

Fondo Indigena. (2019). Indian Background: 24 Years of Working with Indigenous Peoples. Retrieved from http://www.fondoindigena.org/drupal/ en/node/513.

Hidalgo-Capitán, A. L., Cubillo-Guevara, A. P., \& Masabalín-Caisaguano, F. (2019). The Ecuadorian Indigenist School of Good Living (Sumak Kawsay). Ethnicities, 1, 1-26.

Lalander, R. (2016). The Ecuadorian Resource Dilemma: Sumak Kawsay or Development? Critical Sociology, 42(4-5), 623-642.

Larrea, C. (2009). Yasuni-ITT Initiative: A Big Idea from a Small Country. UNDP. Masala, R., \& Monni, S. (2017). The Social Inclusion of Indigenous Peoples in Ecuador Before and After the Revolucion Ciudadana. SEEDS Working Paper, 10/2017. Retrieved from http://www.sustainability-seeds.org/papers/ RePec/srt/wpaper/1017.pdf.

Radcliffe, S. A., Laurie, N., \& Andolina, R. (2002). Indigenous People and Political Transnationalism: Globalization from Below Meets Globalization from Above?. University of Oxford. Transnational Communities Programme.

Ramírez Gallegos, R. (2012) Izquierda y 'buen capitalismo'. Un aporte crítico desde América Latina. Nueva Sociedad 237: 32-48. Retrieved May 3, 2013, from http://www.nuso.org/upload/articulos/3818_1.pdf.

Republica del Ecuador. (2008). Constitución de la República del Ecuador. Quito: Tribunal Constitucional del Ecuador. Registro oficial Nro, 449.

Schilling-Vacaflor, A. (2010). Bolivia's New Constitution: Towards Participatory Democracy and Political Pluralism? European Review of Latin American and Caribbean Studies, 90, 3-22.

Sistema Integrado de Indicadores Sociales del Ecuador (SIISE). (2015). Indicadores sociales del Ecuador. Retrieved September 20, 2015, from http:// www.siise.gob.ec/siiseweb/.

Uzendoski, M. A. (2018). Amazonia and the Cultural Politics of Extractivism: Sumak Kawsay and Block 20 of Ecuador. Cultural Studies, 32(3), 364-388.

van Nieuwkoop, M., \& Uquillas, J. E. (2000). Defining Ethno-Development in Operational Terms: Lessons from the Ecuador Indigenous and Afro-Ecuadoran Peoples Development Project. Working Paper No. 6, World Bank, Latin American and Caribbean Regional Office, Environmentally and Socially Sustainable Development SMU, Washington, DC.

Villalba-Eguiluz, C. U., \& Etxano, I. (2017). Buen Vivir vs Development (II): The Limits of (Neo-Extractivism). Ecological Economics, 138, 1-11. 
World Bank. (2019). Indigenous and Afro-Ecuadorian Peoples' Development Project. World Bank Projects and Operations. http://projects.worldbank.org/ P040086/indigenous-afro-ecuadorian-peoples-development-project?lang=en. Yashar, D. J. (1996). Indigenous Protest and Democracy in Latin America. In J. Domínguez \& A. Lowenthal (Eds.), Constructing Democratic Governance: Latin America and the Caribbean in the 1990s: Themes and Issues. Baltimore: The Johns Hopkins University Press.

Yashar, D. J. (1999). Democracy, Indigenous Movements, and Postliberal Challenge in Latin America. World Politics, 52(1), 76-104.

Open Access This chapter is licensed under the terms of the Creative Commons Attribution 4.0 International License (http://creativecommons.org/licenses/ by $/ 4.0 /$ ), which permits use, sharing, adaptation, distribution and reproduction in any medium or format, as long as you give appropriate credit to the original author(s) and the source, provide a link to the Creative Commons licence and indicate if changes were made.

The images or other third party material in this chapter are included in the chapter's Creative Commons licence, unless indicated otherwise in a credit line to the material. If material is not included in the chapter's Creative Commons licence and your intended use is not permitted by statutory regulation or exceeds the permitted use, you will need to obtain permission directly from the copyright holder.

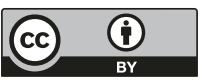

